\title{
Improving Small Cities in California: Clearlake and Bell Community Planning III Studio, Spring 2013
}

\author{
William Siembieda \\ PhD., AICP; Professor and former deparment head; CRP Cal Poly.
}

In this article, professor William Siembieda presents some of the individual projects developed by the MCRP students in-lieu of a thesis or a professional abstract. They choose projects that can be helpful to a local jurisdiction. Presented here are four projects developed in the class for the cities of Clearlake and Bell, California.

$\mathrm{M}$ ost small towns have several unmet planning needs. Helping to meet these needs is a valued outcome of the Community and Regional Planning Studio III (CRP 556), an option for MCRP students who prefer not to pursue a master's thesis or who have not identified their own client for a master's professional project. Following a two-quarter-long studio when a class studies a community and develops a general plan - often through a contract with a local jurisdiction or public entity- in CRP 556 students choose from a list of projects to be developed individually for that same community in one quarter (ten-weeks). These projects have to fulfill a local planning need as identified by the instructors and local jurisdictions.

This article presents work done in the spring of 2013 for the cities of Clearlake and Bell, California. Clearlake is a freestanding rural city in Northern California, while Bell is an urban city in the Los Angeles region. Four of eleven projects are featured in this article while the complete list of projects from this class is presented in Table 1.

\section{Clearlake}

Clearlake, an incorporated city of 15,000 people in Lake County, is 80 miles north of San Francisco. This community of 10.8 square miles is located adjacent to Clear Lake, the state's largest fresh water lake. The residents enjoy a rural life style and its economy is dependent on tourism.

\section{Project: Template for EIR}

In California, a General Plan Update requires conducting an Environmental Impact Report. This costly, and timeconsuming task is assisted by Kathryn Slama's project: a Program EIR Template for the General Plan. A program level EIR evaluates the implications on the environment as a result of adopting a planning document, such as a general plan which provides direction for long-term visioning and broad community goals.

This EIR template is used to assess all elements of the

Table 1: Students' project titles and cities.

\begin{tabular}{|r|l|l|l|}
\hline & \multicolumn{1}{|c|}{ Student Name } & \multicolumn{1}{|c|}{ Title } & \multicolumn{1}{c|}{ City/County } \\
\hline 1 & Michael Christensen & Accessory Dwelling Unit Ordinance & City of Bell \\
\hline 2 & Gabriel Diaz & Transit Oriented Development Design Project & City of Bell \\
\hline 3 & Brian Harrington & General Plan Update Economic Element & City of Bell \\
\hline 4 & Michael Heater & Rails to Trails & City of Bell \\
\hline 5 & Janathan Hidalgo & Healthy Community Element & City of Bell \\
\hline 6 & Abraham Sheppard & LA River Neighborhood Vision Plan & Beill Los Angeles Cnty \\
\hline 7 & Steven Ingoldsby & Air Quality Element & City of Clearlake \\
\hline 8 & Lana Russell. Hurd & Transportation Priority List and Grant Proposal & City of Clearlake \\
\hline 9 & Emma Schoppe & Olympic Drive Design Guidelines & City of Clearlake \\
\hline 10 & Kathryn Slama & GP Update - Draft Environmental Impact Report Template & City of Clearlake \\
\hline 11 & Tan Trango & Directional Signage Plan & City of Clearlake \\
\hline
\end{tabular}




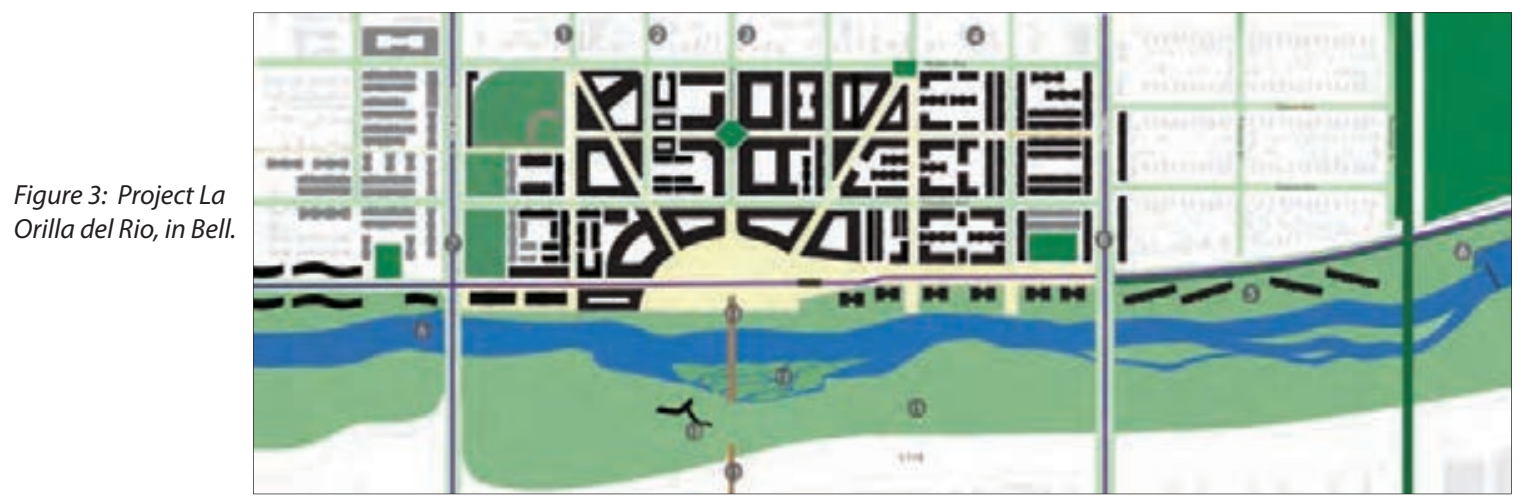

riverfront's potential to become an urban amenity.

Near-term improvements to the channel sides and adjacent land uses can provide recreational amenities in an area that lacks adequate parks and open space. In addition, both near and long term revitalization efforts can be a regenerative force for Bell's neighborhood by La Orilla del Rio - the shores of the river. The plan proposes a three-phased approach for revitalizing the Los Angeles River riverfront and its adjoining neighborhood district.

For the nearer term (5-10 years), the Riverfront Plan envisions new recreational facilities and parks, attractive market-rate and affordable multi-family housing options, and improved river accessibility. This phase incorporates elements that are most likely to be implemented within a tenyear time period. During the mid-term phase (10-20 years), further enhancements are made to the district's circulation network, public infrastructure, and recreational amenities (Figure 3).

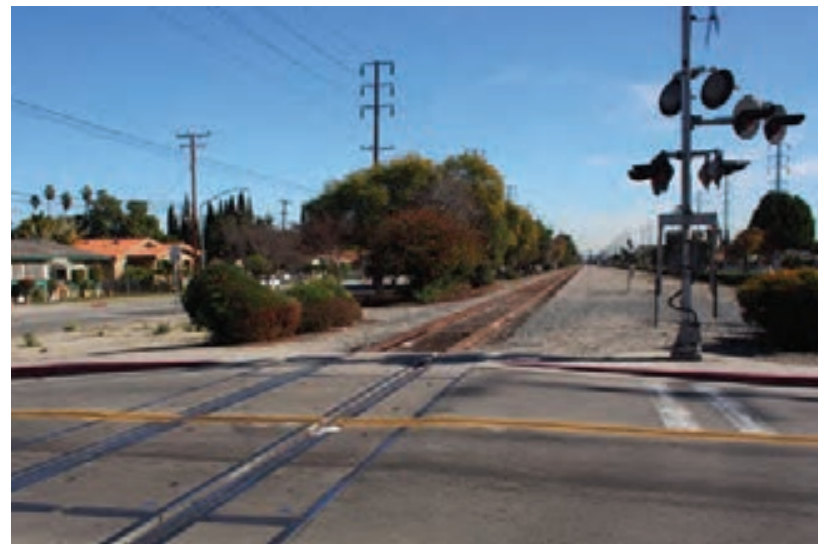

\section{Project: Rail to Trail for Bell}

Bell has a railroad line through the city (Figure 4). An innovative project proposal developed by Michael Heater is the Randolph Street Rail to Trail Feasibility Study. This project examines the potential possibilities for creating a non-motorized, multi-use trail along the rail corridor. The study provides the preliminary foundation needed to plan, design, and construct a rail to trail corridor.

The project would create an east-west bicycle and pedestrian linkage between the City of Huntington Park neighborhood to the north, the City of Maywood neighborhood to the west, and several neighborhoods in the cities of Bell Gardens and Commerce to the east. The project proposes using the existing ROW between 80-120 feet in width to develop the active trails (Figure 5). Creating this trail responds to the city's need for more parks and open space. This project builds on the national movement of utilizing underutilized Right of Way for multiple use purposes.

Figures 4 \& 5: Existing rail's Right of Way in Bell, and an example of the proposed design for rail-trail separation.

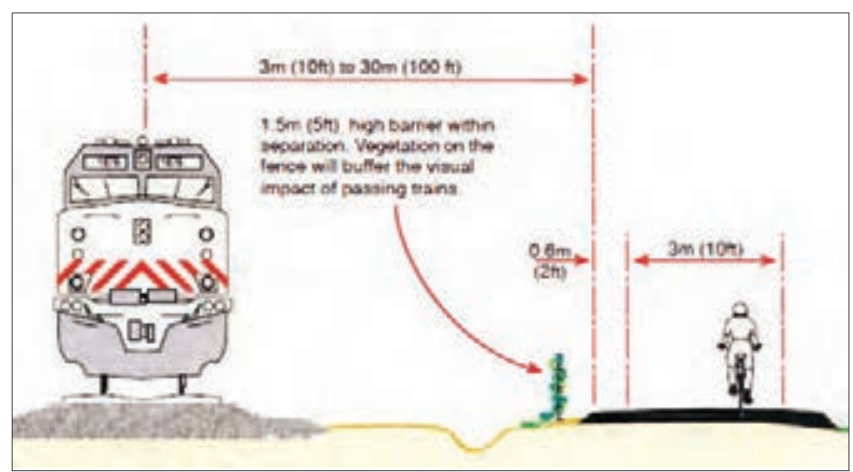

